\title{
Landscape degradation in the world and in Hungary
}

\author{
ÁDÁM KERTÉSZ ${ }^{1}$ and JosEF KŘEČEK²
}

\begin{abstract}
The concept of landscape degradation interprets the process in landscape ecological sense, i.e. the degradation of one landscape forming factor leads to the degradation of the whole landscape. The consequence is a persistent decline in land productivity and in the provision of other ecosystem services. Global environmental change is driven mainly by human influence in the Anthropocene with an exponentially growing significance in time. Global environmental processes are very much interrelated. Because of population growth more food, fibre, clean water, energy etc. will be needed and there are two ways to achieve this, either to gain new areas for cultivation by changing present land use or to intensify cultivation in the areas with the best conditions for cultivation. Deforestation and forest degradation are dealt with in detail in the paper. The introduction of soil degradation processes follows the system given in the EEA Environmental Assessment Report (2003). The effect of landscape degradation on ecosystem services is well explained by the fact that approximately 20 per cent of the Earth's vegetated surface shows persistent declining trends in productivity, mainly as a result of land/water use and management practices (UNCCD 2017). Landscape degradation processes of Hungary are discussed in the paper, including sheet, gully and wind erosion, soil sealing, salinization, physical degradation, landslides, desertification. An estimation of the aesthetical value of the landscape is provided as well concluding that the surface of the country represents a relatively high aesthetical value. The main conclusion is that Hungarian landscapes are well maintained and they belong to the most precious European landscapes. It should be added that all degradation processes represent important environmental problems to be combatted on the basis of a well-established policy making.
\end{abstract}

Keywords: land degradation, landscape degradation, desertification, global environmental change

\section{Introduction}

The degradation of land and of landscapes is one of the most severe problems of the Earth. The concept of land degradation originates from soil degradation and it is often used as a synonym for soil degradation. Landscape degradation means much more than just the degradation of the uppermost layer of the Earth's crust. The landscape is understood as a synthesis of landscape forming factors, therefore the decline of one or more landscape forming factors leads to the degradation of the landscape as a whole. According to Imeson, A. (2012) roughly 20 per cent of global land area is presumably already degraded. The consequence is a persistent decline in land productivity and in the provision of other ecosystem services. The terms "landscape degradation" and "land degradation" will be used alternatively with the same content in this paper.

\section{Global environmental change and land degradation}

A short review of the processes of environmental change from the aspect of land degradation will be provided below. Global

\footnotetext{
${ }^{1}$ Geographical Institute, Research Centre for Astronomy and Earth Sciences, Hungarian Academy of Sciences. H-1112 Budapest, Budaörsi út 45. E-mail: kertesza@iif.hu

${ }^{2}$ Department of Hydrology, Czech Technical University in Prague. Thákurova 7, CZ-166 29 Prague 6. E-mail: josef.krecek@fsv.cvut.cz
} 
environmental change has accompanied the whole history of the Earth. The triggering factors of the changes over the last 200 years, especially recent changes are mainly due to human activities. These changes are different from those of natural origin. Anthropogenic changes driven by human activities are very significant for the structure and function of ecosystems to the Earth system, with equally far-reaching consequences for human wellbeing (Turner, B.L. et al. 2008). The processes of global environmental change are so much interrelated that it is difficult to separate them and report exclusively on a single process.

\section{Population growth}

World population in 2019 is 7.7 billion people and it is expected to be almost 10 billion people by 2050 (World Population Clock 2019). The urban population in 2019 is about 4.26 billion, i.e. 55 per cent of the total population in the world. It should be mentioned that the rate of global population growth is declining. The current growing rate (2018-2019) is 1.07 per cent per year, less than in 2017 (1.09\% per year) and in 2016 (1.14\% per year). The regional distribution is as follows: Asia 59.4 per cent, Africa 17.1 per cent, Europe 9.6 per cent, Latin America and the Caribbean 8.5 per cent, North America 4.8 per cent, Australia and Oceania 0.5 per cent. The share of the developing world is 85.6 per cent.

Analysing the data from the aspect of landscape degradation it is obvious that

- the constantly growing population even at a lower growth rate will require more food, fibre, clean water, energy etc. and there are two ways to achieve this, either to gain new areas for cultivation by changing present land use, or to intensify cultivation in the areas with the best conditions for cultivation;

- the huge percentage of urban population means an increase of sealed area, water and air pollution, a growing amount of waste etc.;
- the population percentage of the developing world makes a huge impact on the developing countries from various aspects including landscape degradation and it triggers an ever growing trend of migration from these countries.

\section{Climate change}

Although climate change has been happening throughout the Earth's history as a consequence of natural causes, recent changes of the climate are mainly due to human activities. The sources of human-released greenhouse gases are well known. They originate from emissions associated with energy use, but on local and regional scales, urbanization and land use changes are also important. "These changes will be increasingly manifested in important and tangible ways, such as changes in extremes of temperature and precipitation, decreases in seasonal and perennial snow and ice extent, and sea level rise" (CARL, T.R. and Trenberth, K.E. 2003). The main anthropogenic activities related to the emission of green-house gases before the industrial revolution were irrigation and deforestation (Turner, B.L. et al. 2008).

The IPCC special report informs about the impacts of global warming of $1.5^{\circ} \mathrm{C}$ above pre-industrial levels (IPCC 2018). Climate models project big differences in regional climate characteristics between present-day and global warming of $1.5^{\circ} \mathrm{C}$, and between $1.5^{\circ} \mathrm{C}$ and $2{ }^{\circ} \mathrm{C}$.

The differences are as follows: increases in mean temperature in most land and ocean regions (high confidence), hot extremes in most inhabited regions (high confidence), heavy precipitation in several regions (medium confidence), and the probability of drought and precipitation deficits in some regions (medium confidence, IPCC 2018).

From the aspect of landscape degradation temperature increase, precipitation decrease and the augmenting risk of the intensity and frequency of droughts and high intensity rainfall events, i.e. increases in frequency, 
intensity, and/or amount of heavy precipitation, as well as other climate and weather extremes point to the possible acceleration of land degradation and desertification processes in some regions of the Earth. Risks from droughts and precipitation deficits are projected to be higher at $2{ }^{\circ} \mathrm{C}$ compared to $1.5^{\circ} \mathrm{C}$ of global warming in some regions (medium confidence, IPCC 2018).

Climate change is a major factor influencing desertification processes, the global importance of desertification will increase and it is and it will be the most important group of land degradation processes in those regions of the world where the climate is arid, semi-arid or dry sub-humid.

\section{Land use change}

Up to the end of the $20^{\text {th }}$ century 50 per cent of the Earth's ice-free land surface has been transformed and much of this change is a direct consequence of land use type (Turner, B.L. et al. 2008). Landscape change is one major characteristic of recent environmental change across Europe (LundBerg, A. 2018).

The use of land in order to yield goods and services represents the most substantial human alteration of the Earth's system. Human use of land changes the structure and functioning of ecosystems, and it alters how ecosystems interact with the atmosphere, with aquatic systems, and with surrounding land (Vitousek, P.M. et al. 1997).

Land Use and Land Cover Changes (LULCC) are strongly connected to other processes of global change, especially to climate change, population growth and land degradation. Land use/land cover changes are responsible for 35 per cent of human-induced $\mathrm{CO}_{2}$ equivalents (Foley, J.A. et al. 2005) pointing to the relationship with climate change. As discussed above, the increasing need for food requires new fields for agricultural production. The new agricultural areas in most cases replace former forests. If the forest is cut land degradation will take place. If agricultural areas already in use are used more intensively, land degradation will increase as well.

In addition to the increase of the areas used for agriculture, urban and industrial areas are growing, too. Urban intensification is accompanied by large increases in resource consumption, habitat fragmentation and biodiversity loss (Foley, J.A. et al. 2005; LAWLER, J.J. et al. 2014; Kertész, Á. et al. 2019).

The global expansion of agricultural, urban and industrial areas was accompanied by large increases in energy, water, and fertilizer consumption and they potentially undermine the capacity of ecosystems to sustain food production, maintain freshwater and forest resources, regulate climate and air quality, and ameliorate infectious diseases (Foley, J.A. et al. 2005).

\section{Landscape degradation}

Land degradation and landscape degradation research have become extremely important during the past decades. According to BARRow land degradation can be defined "as the loss of utility or the reduction, loss or change of features or organisms which cannot be replaced" (BARrow, C.J. 1991). The land is degraded when "it suffers a loss of intrinsic qualities or a decline in its capabilities" (Blaikie, P. and Brookfield, H. 1987). The UNEP (1992) definition emphasizes the reduction of the potential of natural resources as a result of processes acting in the landscape.

Johnson, D.L. and Lewis, L.A. (1995) underlined the role of human interventions in land degradation and focused on the reduction of biological production and/or the utility of an area.

Land degradation means the reduction or loss of biological productivity and the negative effects on the functioning of the land and the related ecosystems (Hudson, P.F. and Alcántara-Ayala, I. 2006). In this paper the terms of land and landscape degradation will be used with the same meaning, i.e. meaning landscape degradation. 
According to the Intergovernmental Platform on Biodiversity and Ecosystem Services "degradation of the Earth's land surface through human activities is negatively impacting the well-being of at least 3.2 billion people, pushing the planet towards a sixth mass species extinction, and costing more than 10 per cent of the annual global gross product in loss of biodiversity and ecosystem services. Loss of ecosystem services through land degradation has reached high levels in many parts of the world, resulting in negative impacts that challenge the coping capacity of human ingenuity. Groups in situations of vulnerability feel the greatest negative effects of land degradation, and often experience them first. These groups also see the greatest benefits from avoiding, reducing and reversing land degradation. The main direct drivers of land degradation and associated biodiversity loss are expansion of crop and grazing lands into native vegetation, unsustainable agricultural and forestry practices, climate change, and, in specific areas, urban expansion, infrastructure development and extractive industry." (IPBES 2018).

The IPBES definition for degraded land is as follows: "degraded land is a state of land which results from the persistent decline or loss in biodiversity, ecosystem functions and services that cannot fully recover unaided within decadal time scales. Land degradation is a myriad of processes that drive the decline or loss in biodiversity, ecosystem functions or services, and includes the degradation of freshwater and coastal ecosystems which are closely interconnected with terrestrial ecosystems".

There are various estimations on the percentage of degraded land ranging between 20 and 75 per cent (see the Introduction). The most recent data published in the World Atlas of Desertification (CHerlet, M. et al. 2018) are as follows: over 75 per cent of the Earth's land area is already degraded, and over 90 per cent could become degraded by 2050. Globally 4.18 million $\mathrm{km}^{2}$ is degraded annually, with Africa and Asia being the most affected.

\section{Deforestation (forest area change) and forest degradation}

\section{Forest degradation}

Deforestation as one of the most important and most dangerous global processes will be presented in detail below. The degradation and devastation of forests is a very serious problem as well.

(a) Environmental services of forests. Generally, forests are considered making vital contributions both to people and the planet, conserving biodiversity, soil and water, and responding to climate change (FAO, 2018). The majority, 76 per cent of the global forest area are public forests with a perspective of sustainable management. Willis, K.G. (2002) categorised the main non-market costs and benefits of forestry practices in headwater catchments, where the principal products include: (1) abstraction for potable water (for drinking and commercial uses), (2) agriculture and irrigation in down-stream areas, (3) hydro-electric power generation, (4) wildlife (including recreational and commercial fisheries), and (5) other recreational uses. According to the data of FAO (2018), the global percentage of forests managed for soil and water protection is 25 per cent: the highest in North and Central America (71\%), 12 per cent in Europe, and the lowest in Africa (8\%). Forest degradation is defined as a reduction in the capacity of ecosystem services as a result of anthropogenic and environmental changes, and, the presence of soil erosion is a prime indicator of forest degradation (FAO, 2011).

(b) Regional drivers of forest degradation. Although the reduction of the global forest area stopped recently (UNFF, 2017; FAO, 2018); 30 per cent of global forest cover has been cleared and another 20 per cent degraded losing their capacity to provide services to people and nature, most of the rest has been fragmented, leaving only about 15 per cent intact. Overall, agricultural use is responsible for around 80 per cent of deforestation worldwide; concerning the developing coun- 
tries (Hosonuma, N. et al. 2012); commercial agriculture is the most important driver in Latin America (68\% contrary to around 35\% in Africa and Asia) while the effects of local agriculture are equally distributed among the continents (27-40\%). IUCN (2017) reported that over half of the tropical forests have been destroyed since the 1960s by the conversion of forest to agriculture land.

In Europe, forests cover 38 per cent of the land area (EEA, 2007 - Figure 1): about three quarters of them are considered 'undisturbed' (mostly located in the Russian Federation). The devastating pressure on European forests is caused particularly by air pollution (mainly in Central and Eastern Europe), and fire (which is a major concern in Southern Europe). On average 700,000 hectares of wooded land in Europe are burnt each year by a total of 60,000 fires (FAO, 2011). According to (EEA, 2017), the most harmful air pollutants in terms of damage to forests are ozone $\left(\mathrm{O}_{3}\right)$, ammonia $\left(\mathrm{NH}_{3}\right)$ and nitrogen oxides $\left(\mathrm{NO}_{\mathrm{x}}\right)$. However, 3.7 million hectares of Europe's forests were damaged by acid rain impacts initiated by sulphur emissions culminating in the middle of the 1980s. The exceedance of acidity critical loads in 2000 is shown in Figure 2. In 2014, transboundary air pollution exceeded the critical level for the protection of forests over 68 per cent of the total EU-28 forest area (EEA, 2017).

The acid rain calamity in the 'European Black Triangle' (the border area of the Czech Republic, Germany and Poland) lead to an extended commercial harvest of spruce plantations (Picea abies) replaced by Junco effusi-Calamagrostietum villosae community with dominant grass cover (Ǩ̌̌ĚEK, J. and Hoर̌ICKÁ, Z. 2006). In 1982 and 2015, effects of forest clear-cut were studied in the Jizerka experimental catchment (the Jizera Mountains, Czech Republic). Skidding the timber by wheeled tractors caused 10.3 per $\mathrm{km}$ of skid trails and the drainage density increased from 1.45 to 7.55 per $\mathrm{km}$ (Figure 3). On the harvested runoff plots, not affected by skid trails, the loss of soil 0.007-0.014 mm per year was comparable

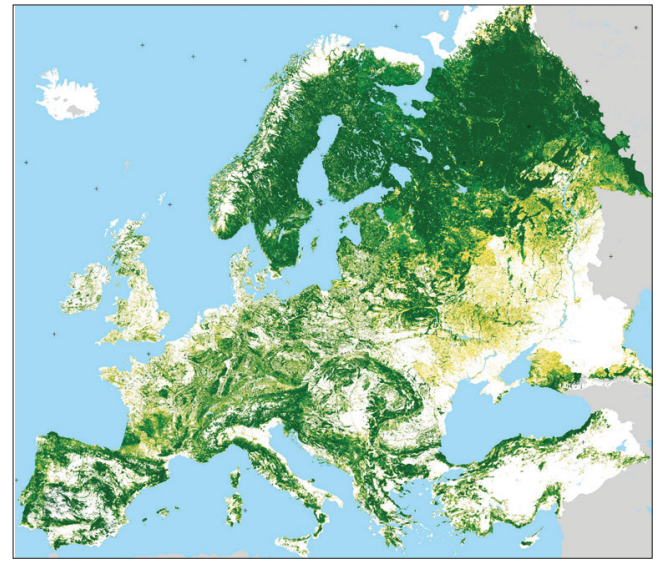

Fig. 1. European forest cover (light yellow 0-5\%, dark green $>60 \%)$. Source: EEA (2007).

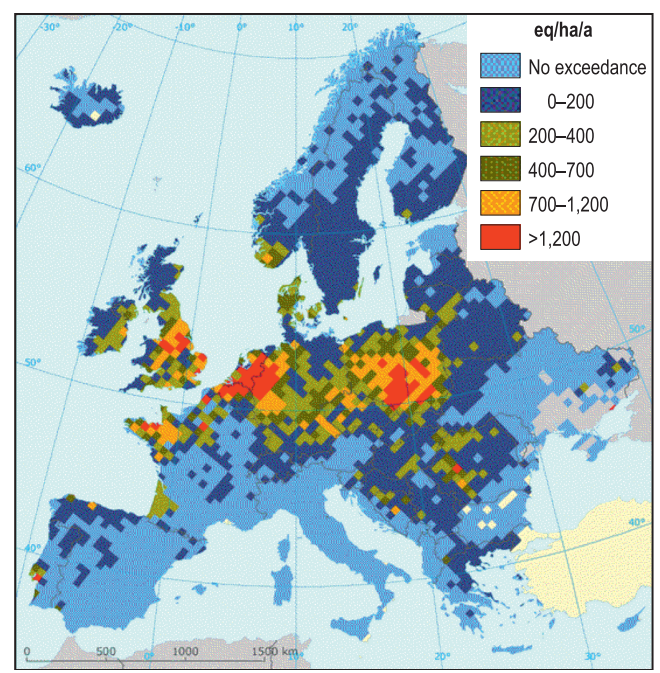

Fig. 2. European exceedance of critical acidity loads in 2000. Source: EEA (2017).

with undisturbed forests. But, the eroded soil in skid trails reached $6.17 \mathrm{~mm}\left(61.73 \mathrm{~m}^{3}\right.$ per ha) by harvesting $23,882 \mathrm{~m}^{3}$ of timber (i.e. 0.25 $\mathrm{m}^{3}$ per $\mathrm{m}^{3}$ of harvested timber). At the catchment outlet, sediment yield reached 25 per cent of the eroded soil. Natural regeneration of erosion rills was supported particularly by the development of herbaceous vegetation. 

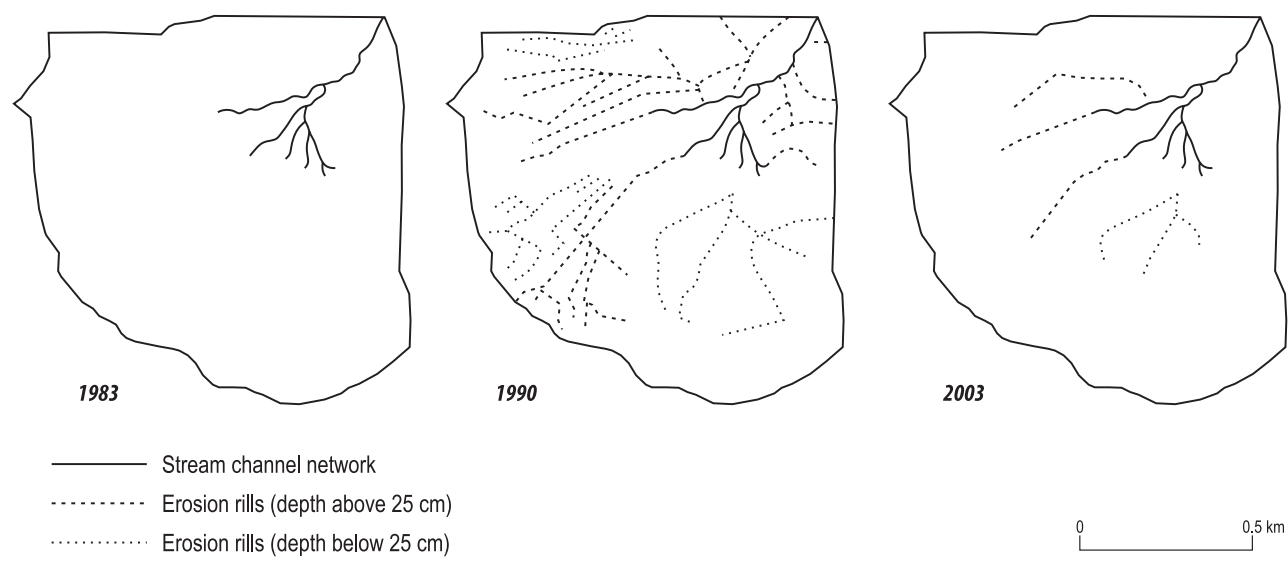

Fig. 3. Drainage network and erosion rills in the Jizerka catchment before (1983) and after the forest harvest (1990, 2003). Source: Кর̌EČEK, J. et al. (2018).

In 2003, twelve years after the logging, only $1.5 \mathrm{~km}(15 \%)$ of active deeper rills were still identified (К̌̌̌Ě̌K, J. et al. 2017a).

\section{Forest conservation and recovery}

About 7 per cent of the European forest area is under protection and about 3 per cent under strict protection. Nature-based solutions for managing forests for soil and water protection and forest landscape restoration can reverse the effects of deforestation and degradation and regain the ecological, social, climatic and economic benefits of forests. But, due to the complex nature of forests, the ecosystem services they provide, especially water-related services are often misunderstood, undervalued, and therefore overlooked (Ǩ̌̌̌čEK, J. et al. 2017b). In the near future, dominant spruce stands in mountain catchments will be endangered by impacts of the global climate change (increasing global temperatures by $1.4-5.8^{\circ} \mathrm{C}$ till 2100) (EEA, 2003; Christensen, J.H. 2005) as well as by more frequent floods and draughts. The risks of climate change will be considerably higher and less manageable in those countries which already suffer significantly from drought stress such as the Mediterranean countries.

\section{Soil degradation}

Land degradation and climate change are estimated to lead to a reduction of global crop yields by about 10 per cent by 2050. In India, China and sub-Saharan Africa land degradation could bisect crop production. By 2050, up to 700 million people are estimated to have been displaced due to issues linked to scarce land resources. The figure could reach up to 10 billion by the end of this century (Cherlet, M. et al. 2018).

Future land degradation will be, of course, different in various parts of the world. According to Crosson, P.R. (1997) an accelerating rate of degradation $(0.4 \%)$ can be assumed for the coming 30 years, accompanied by a decline of altogether 17 per cent of agricultural activity. Land degradation will not be a serious threat to food supply because this supply will come from the non-degrading lands.

In soil science the terms "land degradation" and "soil degradation" are often used with the same meaning. Soil degradation processes belong to land and landscape degradation processes because the degradation of the soil leads to the degradation of all landscape forming factors (see Introduction).

In the EEA Environmental Assessment Report (2003) the following soil degradation 
processes are mentioned, with special emphasis on European soils:

(1) Soil sealing. It is a unique and very important harmful process as the result of soil sealing is the isolation of the soil from the atmosphere, hydrosphere and the biosphere. The soil is covered by an impervious material. The areas affected are settlements and transportation infrastructures. One of the most significant consequences is that the water on sealed surfaces is running off without any filtration with an increased speed and in great quantities.

Sealed surfaces are lost to other land uses (e.g. agriculture and forestry). Ecological soil functions, e.g. carbon storage and habitat for unique biota are limited or hampered. Soil sealing can lead to habitat fragmentation and to the disruption of migration corridors for wildlife species.

(2) Soil erosion by water and wind. As every degradation process, soil erosion has also been exacerbated by human activities, especially by the extension of agriculture to the hilly, sloping areas and so soil erosion can be regarded as one of the major and most widespread forms of land degradation. According to Oldeman, L.R. et al. (1991) about 17 per cent of the total land area in Europe is affected by soil erosion to some extent. According to Eurostat (2018), based on a study performed by Joint Research Centre, approximately 11.4 per cent of the EU territory is estimated to be affected by moderate to high level soil erosion rate (more than 5 tons per ha per year). A previous assessment estimated the percentage of the area affected by soil erosion at 16 per cent (EEA, 2003). The explanation for this reduction is due to the application of management practices against soil erosion. Mean rates of soil erosion by water amounted to 2.4 tons per ha per year. The total annual soil loss in the EU is estimated at 950 megatons (Eurostat, 2018).

Unsustainable agricultural practices, the lack of measures against soil erosion in some areas, large-scale farming, overgrazing, poor water management and forest fires in the Mediterranean region are the most signifi- cant influencing factors of soil erosion. In Europe soil erosion by water acts on about 92 per cent of the total area affected by erosion. Wind erosion is less important and it is localized to some areas of Western, Central and Eastern Europe. It should be mentioned, however, that wind erosion played an extremely important role in the establishment of the Soil Conservation Service of the United States in the 1920s.

Land degradation is accompanied by a negative effect on productivity. According to Pimentel, D. et al. (1993) soil erosion causes 15-30 per cent less production. Nutrient depletion because of erosion leads to 29 per cent decline of crop production and 19 per cent loss in total production. An additional negative effect is yield reduction (e.g. yield reduction in Africa due to past soil erosion may range from 2 to 40 per cent, with a mean loss of 8.2 per cent for the continent (Eswaran, H. et al. 1999). The relationship between erosion and productivity can be expressed by a negatively-exponential curve, i.e. production diminishes very rapidly in the early stages of erosion. Different soil types show, of course, different patterns (Tengberg, A. and Stocking, M. 1997).

(3) Soil contamination from non-point (diffuse) and point sources causes damage of several soil functions and the contamination of groundwater and surface water. The main non-point sources of soil contamination are the deposition from runoff, surface waters and from the eroded soil, atmospheric deposition (acidification and eutrophication compounds, fertilizers, pesticides, sewage sludge and manure which may contain heavy metals, too). Contamination from point sources can originate from industrial plants no longer in operation, municipal and industrial waste disposals and former industrial accidents (EEA, 2003). Operating industrial plants and mining sites are a contamination risk for soils and groundwater.

(4) Salinization, i.e. the accumulation of water-soluble salts near the soil surface is an important soil degradation process in Europe. Saltwater intrusion in the Mediterranean and 
inland salinization mainly in Eastern and South Eastern Europe as well as secondary salinization due to the application of salt rich irrigation water lead to unproductive soils and other environmental problems. The latter points to the role of human society mainly by inappropriate irrigation practices. The area affected by salinization is estimated to cover 3.8 million ha in Europe (EEA, 1995). The global estimate of the area made unusable by secondary salinization is 1 million ha in a year. In advanced stages salinization may lead to the extirpation of vegetation and to transforming fertile land to barren and the end of the process can be desertified land.

(5) Soil compaction is mainly the consequence of the repetitive and cumulative effect of heavy machinery. Soil compaction decreases infiltration, increases surface runoff and leads to accelerated water erosion accompanied by the loss of topsoil and nutrients. Biochemical and microbiological activities will change, too. Topsoil compaction can be easily handled while subsoil compaction is persistent and difficult to be reversed.

The first global survey of land (soil) degradation, GLASOD (Global Assessment of Soil Degradation) was performed by OLDEMAN, H. et al. (1991). It contains the extension of various forms of soil degradation (water and wind erosion, chemical and physical degradation), the rate of degradation (light, moderate, strong, extreme) and the causes of degradation (deforestation, overgrazing, improper farming, overexploitation, contamination). According to this survey 3.7 per cent of the Earth's surface is affected by physical and chemical degradation and 12 per cent by water and wind erosion.

According to Oldeman, H. et al. (1991) 38 per cent of the agricultural area of the Earth is degraded. The percentage of degraded areas in Africa is 65 per cent, in Central America 74 per cent and in South America 45 per cent. The proportion of degraded pasture and forests is smaller ( $21 \%$ and $18 \%$, respectively). Considering agricultural area, permanent pasture and forests together, the percentage of degraded area is 23 per cent.

\section{Land degradation and ecosystem services}

Ecosystem services are "the benefits people obtain from ecosystems" (Millennium Ecosystem Assessment, 2006). The four categories of ecosystem services are as follows:

- supporting services provide the basic conditions for life, e.g. fertile soils;

- regulating services provide the functioning of ecosystems, e.g. flood and decease control;

- provisioning services belong to the third group (e.g. food, water, fuel, wood);

- the cultural services include e.g. recreational, cultural benefits.

Because of the significance and critical state of ecosystem services an international platform was created: The Intergovernmental Science-Policy Platform on Biodiversity and Ecosystem Services (IPBES) which is an intergovernmental body on the state of biodiversity and of the ecosystem services. The Millennium Ecosystem Assessment (Millennium Ecosystem Assessment, 2006) preceded IPBES. The thematic assessment of land degradation and restoration is deliverable 3(b)(i) of the IPBES working program (IPBES, 2019).

According The Global Land Outlook a significant proportion of managed and natural ecosystems are degrading: over the last two decades, approximately 20 per cent of the Earth's vegetated surface shows persistent declining trends in productivity, mainly as a result of land/water use and management practices (UNCCD 2017). Land degradation reduces the quality of land in multiple ways. Improper land use leads to long-term losses of ecosystem function and productivity.

\section{Desertification}

The term of desertification was first mentioned in the 1920s (BoviLL, E.W. 1921, cited by Herrmann, S.M. and Hutchinson, C.F. 2005) when the extension of the West African Sahara into the Sahel zone was first observed. Aubreville used the term first (Aubreville, 
A. 1949) describing the change of productive land into a desert (Herrmann, S.M. and Hutchinson, C.F. 2005). This statement indicated that the term desertification is always connected with human activities, with land mismanagement.

Drylands have a huge extension covering approximatively 40 per cent of the Earth surface. Because of the significance of drylands, it seemed to be appropriate to define a special group of land degradation processes. In 1977 after a series of extremely arid periods in Sahelian Africa UNCOD organized a conference (United Nations Conference on Desertification) in Nairobi. According to the United Nations Intergovernmental Convention to Combat Desertification "Desertification means land degradation in arid, semiarid and dry sub-humid areas resulting from various factors including climate variation and human activities" (UNCOD, 1977). The threshold values of the given climatic zones are defined by the FAO-UNESCO (1977) bioclimatic index: P/ETP (precipitation/potential evapotranspiration, see e.g. KertÉsz, Á. 2009).

The UNCOD definition interprets desertification as a process leading to desert development. This definition concentrates mainly on marginal zones surrounding deserts, like the Sahara-Sahel marginal belt. It should be kept in mind, however, that the process of desertification may not lead to desert development. Proper management can stop and may reverse the process. All concepts agree upon the fact that desertification means severe degradation problems of territories with water deficits and ongoing aridification (Kertész, Á. 2009).

Desertification occurs also in other climate zones (e.g. associated with salinization). If the land is properly managed drought doesn't lead to desertification, not even under arid climatic conditions. Desertification is the result of a combination of drought with land mismanagement (Le Houérou, H.N. 1996). Desertification processes affect 42 million $\mathrm{km}^{2}$ (33\% of the Earth's land surface - EswARAN, H. and ReICH, P. 1998) and some 1 billion peo- ple. According to recent data published by IFAD (2016) about 40 per cent of Earth's land is covered by drylands, and these areas are home to over 2 billion people.

There is uncertainty about the areal extent of desertification. REYNOLDS, J.F. et al. (2003) report that up to 70 per cent of all drylands are 'desertified'; others suggest that the figure is no more than 17 per cent. 37 per cent of global population live on either potentially, or actually degraded land (GisLadottiR, G. and STOcking, M. 2005).

The word "desertification" suggests the gradual disappearing of vegetation and in reality the primary cause of desertification is the removal of vegetation by human activities like deforestation, overgrazing etc. Drought conditions as a result of global warming trigger the sustained growth of vegetation as well. The consequence of vegetation removal leads to the change of the near surface climate leading to surface induration and crusting and hindering infiltration. As a result, soil erosion rates will increase. The upper soil layers, rich in humus and nutrients will be removed and impede the re-establishment of vegetation and the use of the land for agriculture.

The rate of desertification depends also on initial soil moisture content and human interventions, and the latter can be a positive interference. The course and consequences of the process are clear, from the initial status (i.e. sub-humid, semi-arid or arid conditions) proceeding sequentially through the stages (e.g. if the area in question had a sub-humid climate, then undergoing transformation to semi-arid and then arid conditions). As a consequence of ongoing aridification the area may become hyper-arid. In terms of vegetation, steppe will turn into savannah, followed by thorny savannah and then into semi-desert, reaching the ultimate stage of a desert.

\section{Landscape degradation in Hungary}

Land degradation is strongly related to human impact including agricultural activities. 
This statement applies especially for those countries where agriculture still has a considerable contribution to the national economy like in Hungary. According to the data of the Hungarian Central Statistical Office the percentage of the population employed in agriculture is still relatively high, i.e. 10.97 per cent in 2017 (with respect to $9.57 \%$ in 2008). In 20173.3 per cent of the GDP was realized by agriculture. In 2018 the percentage of arable land was 46,59 per cent ( $48.37 \%$ in 2000$)$ and that of agricultural land in 2018 was 57.44 per cent $(62.93 \%$ in 2000$)$. Arable and agricultural land slightly diminishes requiring a more intensive agriculture. A review of the most relevant publications on landscape degradation processes will not be provided below because of limited space.

\section{Sheet erosion}

Soil erosion is the most important land degradation process in agricultural areas. Agriculture is extended to the hilly countries in Hungary and so the risk of soil erosion is very high there. Both sheet and gully erosion are present. 2.3 million hectares are affected by water erosion (13.2\% slightly, $13.6 \%$ moderately and $8.5 \%$ severely eroded) and 1.5 million hectares by wind erosion (STEFANOvits, P. and VÁrallyay, Gy. 1992).

Water-erosion processes imply a considerable risk in the mountain and hilly regions because of relief and drainage conditions. A significant area of hillslopes is used for agriculture. Sheet erosion on arable land is especially hazardous on large arable fields created mainly in the 1960s and 1970s. The main triggering factors of water erosion are soil parent material (easily erodible loose sediments), slope gradient, high intensity rainfalls and land use. In summer, after the harvest, exactly in the period when extreme rainfalls are likely to happen the surface is without vegetation cover, implying a high soil erosion risk.

Soil erosion maps compiled during the last 5-6 decades present actually soil erosion sen- sitivity. The given soil loss values indicate the degree of erosion so that in reality it is a degree on a scale between slight and strong erosion which is behind the values given as soil loss, in tons per hectare.

The most recent soil erosion map was prepared in the Institute for Soil Sciences and Agricultural Chemistry of the Hungarian Academy of Sciences by PÁsztor, L. et al. (2015) (Figure 4). It can be observed on the map that there is a strong relationship between relief and soil loss.

\section{Gully erosion}

The main triggering factors of gully erosion in Hungary are soil parent material (loose sediments), slope gradient, rainfall amount and intensity (especially extreme rainfall events), land use and vegetation cover. Deforestation followed by arable cultivation on hillslopes covered by loose sediments leads to the development of deep gullies within a short time. Soil types and land use play a less important role because they are not independent from relief.

The physical and chemical properties of loess and loess-like sediments promote pipe development. Pipes contribute to gully development, to deepening of the gullies.

The map of gully distribution is shown in Figure 5. Digitized 1:10,000 maps provided the basis for this map. The distribution of the gullies is very high in the mountain forests, developed during a long period of time, whilst the gullies and rills on arable land were labelled before each cultivation operation. Ephemeral gullies are difficult to survey. The high gully density values in the forests reflect intensive soil erosion of former times and this doesn't mean a high erosion risk today.

The major part of the data falls into the categories $<2.5 \mathrm{~m}$ per $\mathrm{km}^{2}$. The highest category of $>25 \mathrm{~m}$ per $\mathrm{km}^{2}$ represents 0.7 per cent of the data. Note that two thirds of the territory of Hungary are lowlands where gully density was not surveyed and so this relatively small value is quite remarkable. 


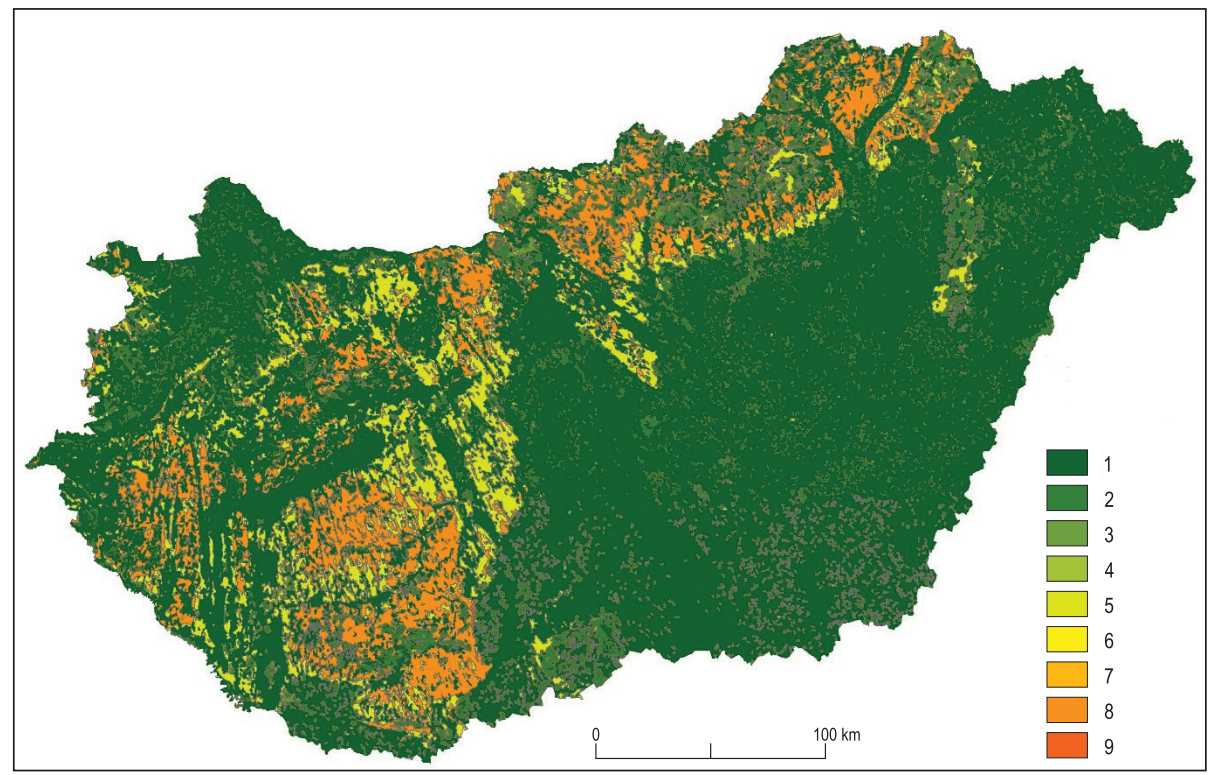

Fig. 4. Soil erosion risk map of Hungary. Source: PÁszTor, L. et al. (2015). The legend categories (1-9) correspond to the following tons per ha per year values: $1=0.0-0.5 ; 2=0.5-1.0 ; 3=1.0-1.5 ; 4=1.5-2.0 ; 5=2.0-5.0 ; 6=5.0-8.0$; $7=8.0-11.0 ; 8=11.0-100.0 ; 9=>100.0$

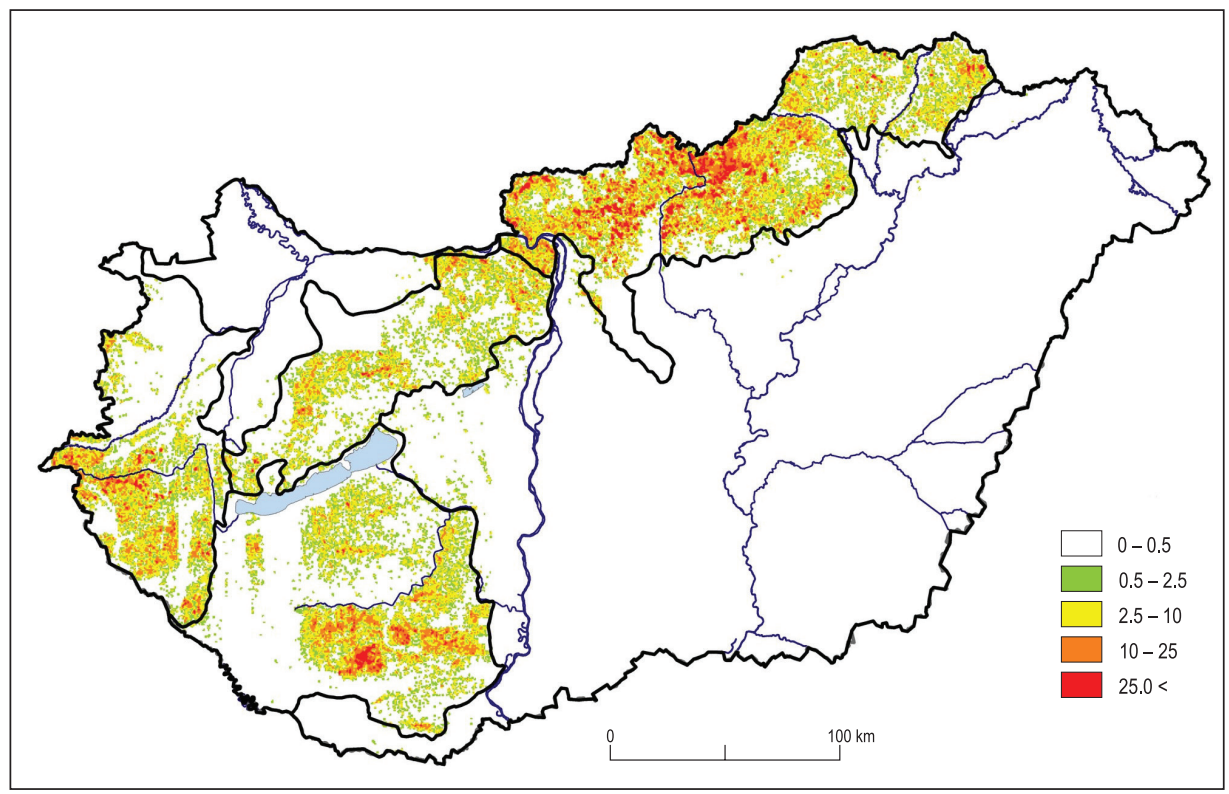

Fig. 5. Gully dissection map of Hungary (km per km²) after JАKAB, G. 2012. Source: Kertész, Á. et al. (2012). 


\section{Wind erosion}

Wind erosion affects 16 per cent of the country area. High wind erosion risk endangers 10 per cent of the surface. 20 per cent of the country area is covered by windblown sand. Sandy soils are obviously prone to wind erosion. In addition to soil parent material the main controlling factors are geomorphology, climate, soil moisture, vegetation, land use and farming practices (FARSANG, A. et al. 2017). Seasonal changes of wind erosion activity are related to soil moisture conditions and to vegetation cover. Wind erosion risk will increase with global change, first of all due to the growing frequency of drought periods. A detailed analysis on wind erosion in Hungary including wind erosion maps is provided in this issue by NéGYEsI, G. et al. (2019).

Soil sealing

The percentage of sealed areas in Hungary in 2012 was 3.21 per cent in 2009 only 3.17 pointing to an increase of almost 10 per cent in four years (EEA, 2017). Figure 6 shows the degree of soil sealing in Hungary. The map was compiled from COPERNICUS data of 2015.

In 2015 the total sealed area covered already 3.98 per cent of the country area. The area of sealed surfaces between 30-60 per cent is 2.1 per cent of the country area and 52.8 per cent of all sealed areas.

If we compare the percentage of sealed areas in Hungary with that of other European countries we come to the conclusion that the value is not very high, it is still acceptable. The reason for this is the high proportion of agricultural, forested and semi-natural areas (e.g. wetlands), like in the cases of France $(2.84 \%)$ and Denmark (3.62\%).

\section{Salinization, secondary salinization}

Concerning extreme soil reaction, both extremes, i.e. acidification and salinization occur in Hungary. Acidification is related to non-calcareous parent material, to leaching and to plant residues decomposition as well as to air pollution and to improper fertilizer application (especially $\mathrm{N}$ fertilizers). The latter is more important (VÁrAllyAy, Gy. 1989) than dry and wet acid deposition.

Salinization is a widespread process in the lowland areas of Hungary. It is important to note that salinization is a natural soil formation process. Today saline areas belong to those of nature protection because they represent a special, unique value and they have to be protected.

Scientific publications on salinization started at the end of the $19^{\text {th }}$ century. The extension of saline areas is one of the largest in Europe, i.e. 560,000 ha occupying 6 per cent of the country area (Тótн, G. et al. 2008). They develop on the Great Hungarian Plain in the areas with shallow salty ground water table (Figure 7).

The development of the areas of secondary salinization is related to human activities. Previously good quality soils become saline because of rising groundwater levels as a result of improper irrigation and inappropriately planned irrigation systems. The estimated area of secondary salinization in Hungary is 400,000 ha (KSH, 1986).

Saline areas are present in 67 natural micro-regions of the country. The largest saline areas are in the following micro-regions: Hortobágy $\left(939 \mathrm{~km}^{2}\right)$, Tiszafüred-Kunhegyes Plain $\left(359 \mathrm{~km}^{2}\right)$, Csongrád Plain $\left(296 \mathrm{~km}^{2}\right)$, Szolnok-Túr Plain $\left(277 \mathrm{~km}^{2}\right)$, Bihar Plain $\left(273 \mathrm{~km}^{2}\right)$ and Dévaványa Plain $\left(268 \mathrm{~km}^{2}\right)$ (Madarász, B. 2019).

The areas sensitive to secondary salinization were determined from water depth data, critical water depth and the saline areas of the agro-topographical map (Figure 8) (Madarász, B. 2019). On the basis of the results it can be asserted that $1 \mathrm{~m}$ rise of groundwater depth would only affect a smaller area $(34,000 \mathrm{ha})$, but in the case of a $1.5 \mathrm{~m}$ rise the size of the areas affected by secondary salinization would be greater than 145,000 ha and the result of a rise of $2 \mathrm{~m}$ it would be 235,700 ha. 


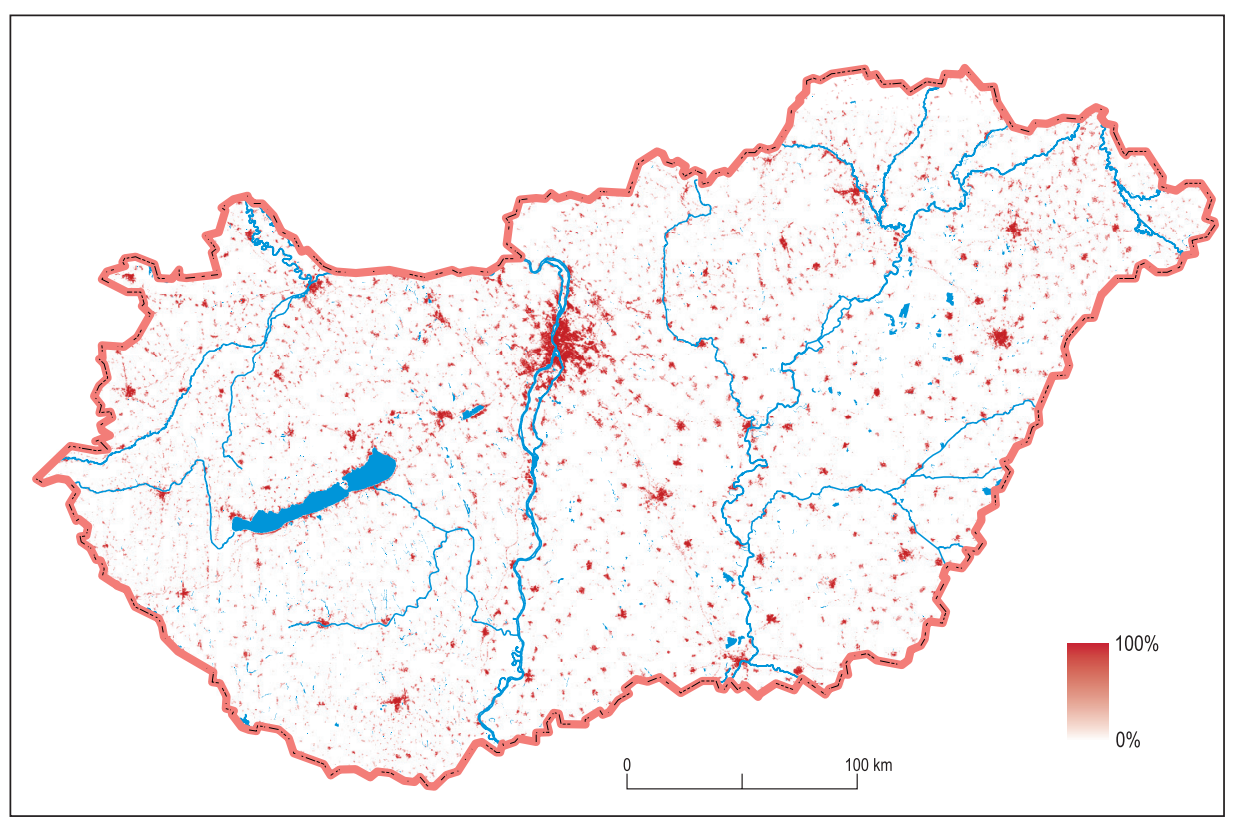

Fig. 6. Soil sealing map of Hungary. (Degree of soil sealing in percentage.)

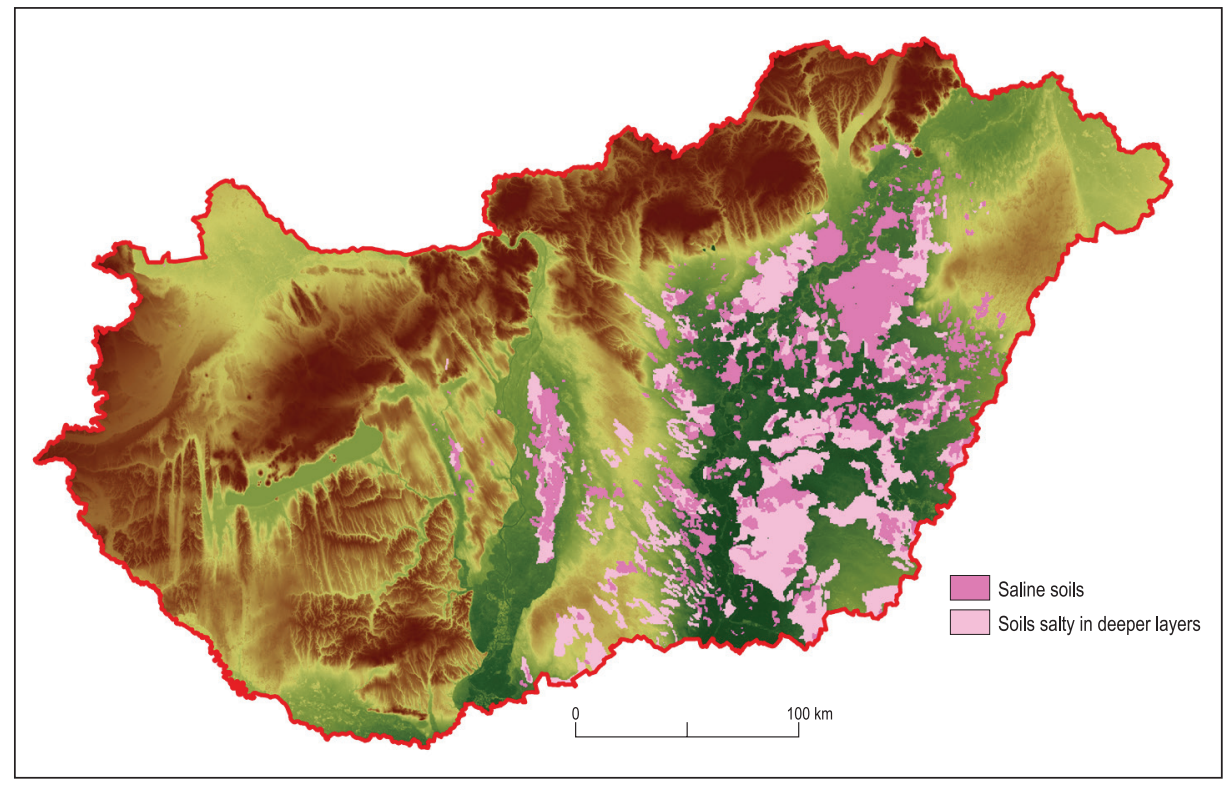

Fig. 7. Saline soils of Hungary. Source: RISSAC (1991) 


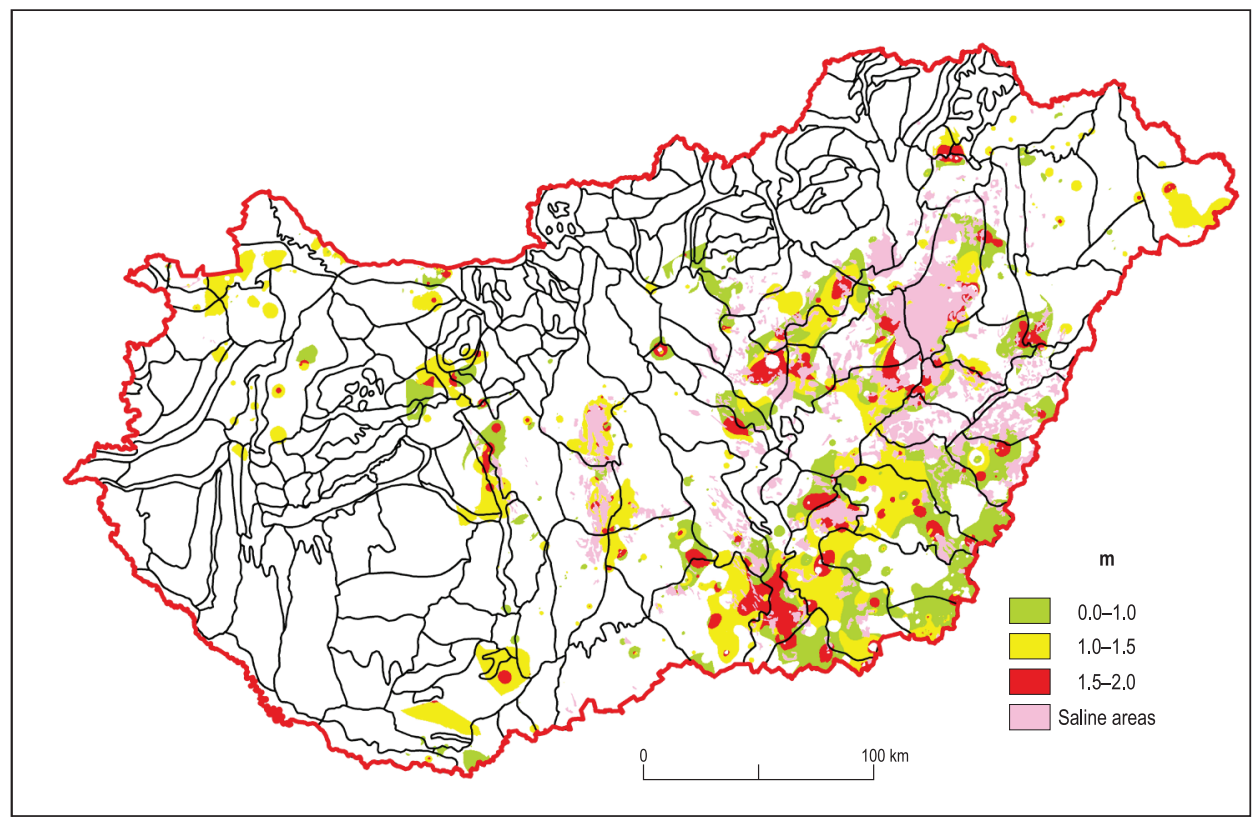

Fig. 8. Extent of areas susceptible to secondary salinization as a function of potential rise of water level. Source: Madarász, B. (2019).

Those areas are the most susceptible and most endangered where the process of salinization can start due to a small water level rise of less than one metre. These territories are attached to existing saline areas along the Tisza, Maros and Körös rivers.

The susceptibility map can be successfully used in decision making and planning preceding new investments and the application of new technologies if they may affect the groundwater level.

\section{Physical degradation}

Human activities, e.g. the application of heavy machinery on intensively cultivated fields are the main triggering factors of physical degradation processes. They include compaction, structure destruction and surface sealing.

A classification system of VÁRALLyAY, GY. and LeszTÁK, M. (1990) was elaborated for
Hungarian soils from the aspect of their susceptibility to physical degradation:

1. Non-susceptible soils: sandy soils without structure and with a low content of cementing compounds (such as carbonates or sesquioxides);

2. Slightly susceptible soils: medium-textured soils with well-developed structure and high aggregate stability;

3. Moderately susceptible soils: mediumtextured soils with moderately developed structure and low aggregate stability;

4. Soils susceptible to compaction and surface crusting but not to structural damage: sandy soils without structure but with a high content of cementing compounds, mainly carbonates;

5. Soils susceptible to structural damage and compaction: heavy-textured soils of swelling-shrinkage character and low structural stability;

6. Soils susceptible to both structural damage and compaction due to salinity-alkalinity; 
7. Organic soils (peats);

8. Shallow soils (solid rock or cemented layer near the surface).

According to Birkás, M. et al. (2000) soil compaction is estimated to be present on nearly 50 per cent of Hungarian cropland. More than 50 per cent of Hungarian soils are subject to physical degradation to some extent. However, their exact extension is not known. According to previous surveys (FARSANG, A. 2011) 13 per cent of Hungarian soils are strongly, 18 per cent moderately and 23 per cent slightly susceptible to physical degradation.

The susceptibility map (Figure 9) was prepared by MADARász, B. (2019), based on the reclassification of soils by texture classes ( 1 = clay, clayey loam, loam; 2 = sandy loam; 3 = sand, peat, coarse fragments), organic material stock $(1=<100 \mathrm{t} / \mathrm{ha} ; 2=100-300 \mathrm{t} / \mathrm{ha}$; $3=>300 \mathrm{t} / \mathrm{ha}$ ). Three CORINE categories were created allowing for weighting soil characteristics data $(0=$ artificial surfaces, e.g. settlements, areas covered with water; 1 = arable land; 2 = forested areas).

The three categories of susceptibility are equally distributed $(29 \%-31 \%-33 \%)$. It is quite probable that global climate change will not seriously effect physical soil degradation. However, if the extent of the areas covered with inland water will increase, it will influence the distribution and extent of the areas susceptible to physical degradation as well.

\section{Landslides}

Landslides are widespread in Hungary because of the wide availability of unconsolidated sediments. They occur on hillslopes, piedmonts, mountains and basins. Mass movement hazard is very significant in the regions where landslides frequently happen.

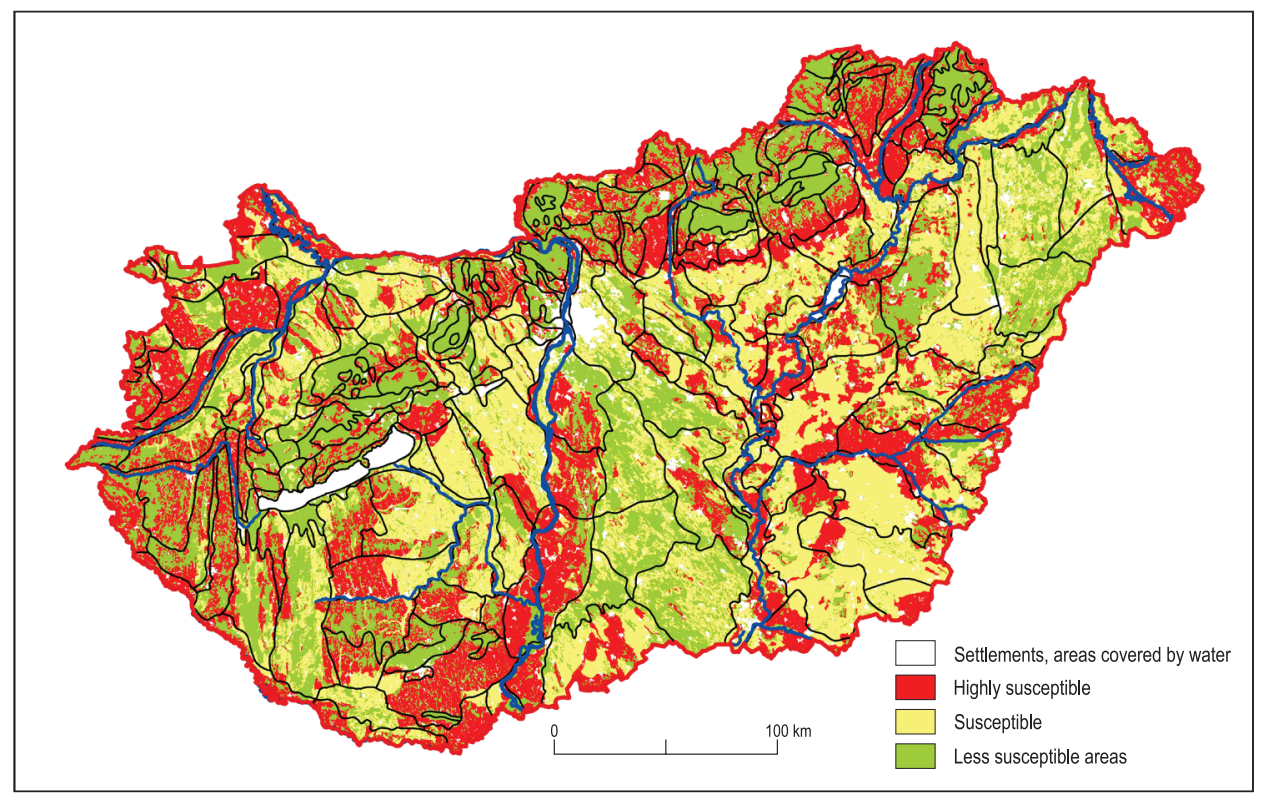

Fig. 9. Areas susceptible to physical degradation. - white $=$ settlements, areas covered by water; red $=$ highly susceptible; yellow = susceptible; green = less susceptible areas. Source: MADARÁsz, B. (2019). 
Most landslides develop on Oligo-Mio-Pliocene clays, sands and marls, with Pleistocene paleosols of high clay content covered by loess mantles of different thickness.

Other important controlling factors of landslide formation are the structure, especially the alternation of permeable and impermeable strata, high relative relief values and a relatively humid climate. Precipitation, especially winter precipitation plays an important role in landslide development.

The location can also be a triggering factor of landslides. They are quite widespread in the valleys of the rivers on riverbanks (e.g. along the Danube, Hernád and Sajó rivers) and along the lake shores of the biggest lakes, i.e. Balaton and Fertő.

The most frequent types are rotational slumps, sliced landslides and layered slides. Human-induced mass movements are typical of spoil heaps in mining districts (JózsA, E. et al. 2019). A detailed analysis of landslide hazard in Hungary is published in this issue by Józsa, E. et al. (2019).

\section{Desertification sensitivity}

Europe including Hungary is also threatened by desertification. Aridification is already present in the central part of Hungary, i.e. in the Danube-Tisza Interfluve. Aridification is understood meaning increasing dryness (aridity) of the climate as a result of global climate change and its environmental consequences. Based on 358 MODIS 8-day composite images drought frequency increased between 2000 and 2014 (Gulácsi, A. and Kovács, F. 2018).

Shorter or longer dry periods in the past have led to serious water deficit and water imbalances affecting natural systems and land resource production systems. The main driving force is the depletion of the groundwater reserves because of less precipitation and high evaporation, the extraction of confined groundwater for drinking water supply, afforestation and other land use changes, drainage regulation, direct groundwater extraction and reduced recharge from the mountains, hills and from the Danube. Desertification risk will grow with climate change.

Climate change in Hungary is primarily characterized by increasing drought sensitivity (FARKAS, J.Zs. et al. 2017). The identification of the areas sensitive to desertification is an important task also for the preparation of decision making. The ESAI index (Environmentally Sensitive Area Index) applied and validated in Mediterranean Europe (Kosmas, C. 1999; BrandT, J. 2005) is the basis of the method to determine desertification sensitivity in the Danube-Tisza Interfluve.

The study area is almost $10,000 \mathrm{~km}^{2}$ including the administrative area of 104 municipalities. Four factors are included in the sensitivity analysis (Figure 10): 1. soil (soil texture, soil water management, SOM content, salinity);
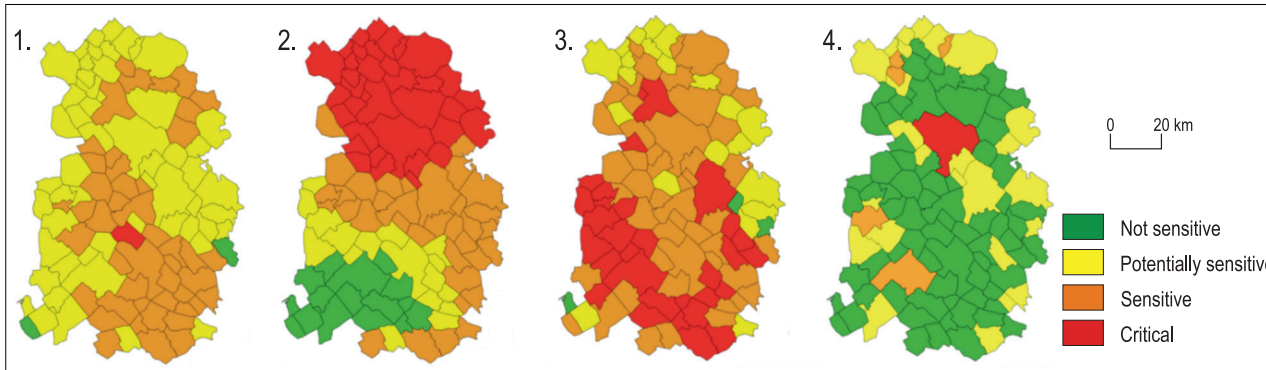

Fig. 10. Soil (1), climate (2), vegetation (3) and land management (4) sensitivity from the aspect of desertification in the Danube-Tisza Interfluve by Örsi, A. Source: Kertész, Á. et al. (2015). 
2. climate (mean annual rainfall [1961-1990], drought index [1961-1990] - PÁlfai, I. et al. 1999); 3. vegetation (percentage of forests, fire risk); 4. land use intensity (KertÉsz, Á. and Örsi, A. 2013; Kertész, Á. et al. 2015). The sensitivity of the vegetation was calculated on the basis of fire risk. The intensity of land use was determined by the total amount of water use per unit area.

Sensitivity to desertification is presented in Figure 11. The north-western and south-eastern parts of the area are the most sensitive to desertification. Figure 11 consists of two maps. Map 1 was prepared by taking only soil, climate and vegetation sensitivity into account. Land use intensity is involved in the analysis on Map 2.

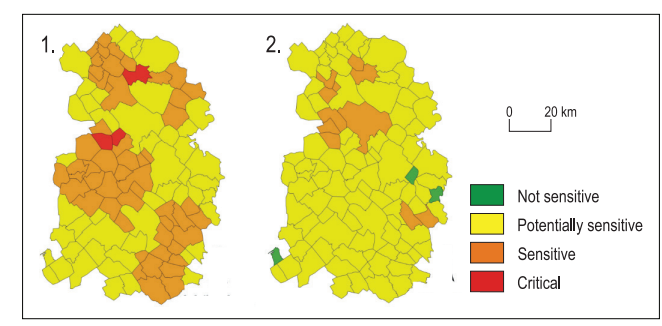

Fig. 11. Desertification sensitivity indices in the Danube-Tisza Interfluve (1) due to natural factors and (2) taking land use intensity into account by ÖrSI, A. Source: Kertész, Á. et al. (2015).

According to climate change scenarios desertification risk will grow. Temperature increase and precipitation decrease accompanied with more frequent and longer periods of drought call for a policy making strategy to combat desertification.

\section{Landscape aesthetics}

This subchapter is not about a landscape degradation process. The aesthetical value of the landscape expresses the situation of the landscapes of Hungary today.
Hungary is a relatively green country with a lot of natural landscape elements and landscapes. The current state of the landscape aesthetical value of Hungary was determined by GIS methods. Landscape elements increasing landscape beauty (relief, forest cover, lakes and rivers, protected areas and vineyards) were evaluated first.

The second step was the evaluation of artificial landscape elements. The classification and evaluation of artificial landscape elements were carried out according to their range and their negative or positive effect on the surrounding landscape.

The landscape aesthetical map of Hungary evaluating both natural and artificial landscape elements is presented in Figure 12.

According to Figure 12 the general statement is that the aesthetical value of Hungarian landscapes is high. The map helps to identify the Hungarian landscapes with outstanding beauty and rich biodiversity. The above maps are useful and easily understandable products for the experts of tourism. The complex evaluation of natural and artificial landscape elements is a valuable supporting tool for decision making.

\section{Conclusions}

The above review of landscape degradation processes in the world and in Hungary is part of the research activity carried out within the framework of an OTKA project (see acknowledgement below).

Comparing the processes of landscape degradation in the world and in Hungary the main conclusion is that the landscapes of Hungary are relatively well maintained and they are part of the most valuable landscapes in Europe. This statement doesn't mean that the above described processes should not be taken seriously. All degradation processes represent important environmental problems which have to be further investigated, analysed and on the basis of these the elaboration of a well-established policy making is necessary. 


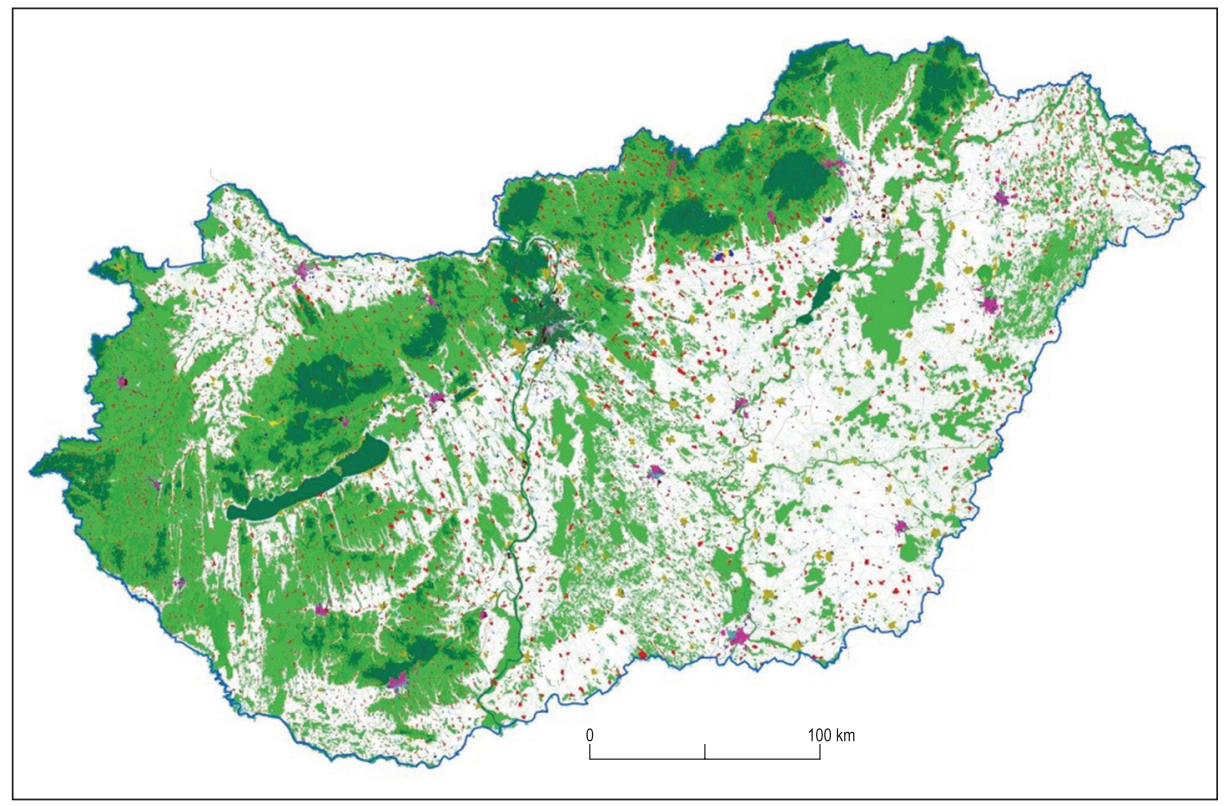

Fig. 12. Aesthetic evaluation of natural (green tones) and artificial (other colours) landscape elements excluding agricultural areas (white).

Acknowledgement: This research is supported by the Hungarian Scientific Research Fund (OTKA), project No. 108755 and the support is gratefully acknowledged here. The research presented in chapter "Deforestation and forest degradation" was supported by the Ministry of Education of the Czech Republic (INTER-EXCELLENCE: INTER-COST LTC 17006).

\section{REFERENCES}

Aubreville, A. 1949. Climats, forêts et désertification de l'Afrique tropicale. Paris, Société des Editions Geographiques, Maritimes et Coloniales.

BArrow, C.J. 1991. Land Degradation: Development and Breakdown of Terrestrial Environments. Cambridge, Cambridge University Press.

Birkás, M., Gyuricza, C., Szalai, T., Jolánkai, M., Gecse, M. and Percze, A. 2000. Crop responses to subsoil compaction. In Proceedings of $2^{\text {nd }}$ Workshop and International Conference on Subsoil Compaction. Eds.: Birkás, M., Gyurica, C., Farkas, C. and Gecse, M., Gödöllő, Szent István University Press.

Blaikie, P. and Brookfield, H. 1987. Land Degradation and Society. London, Methuen.
BrandT, J. 2005. Desertification information system to support. National Action Programmes in the Mediterranean (DISMED). DIS4ME, Desertification Indicator System for Mediterranean Europe. Available at www.unibas.it/desertnet/dis4me/using_dis4me/dismed.htm

Carl, T.R. and Trenberth, K.E. 2003. Modern global climate change. Science 302. 1719-1723.

Cherlet, M., Hutchinson, C., Reynolds, J., Hill, J., Sommer, S. and von Maltitz, G. (eds.) 2018. World Atlas of Desertification. Luxembourg, Office of Official Publications of the European Communities.

Christensen, J.H. 2005. Prediction of regional scenarios and uncertainties for defining European climate change risks and effects (PRUDENCE). Final Report. Copenhagen, Danish Meteorological Institute.

Crosson, P.R. 1997. Will erosion threaten agricultural productivity? Environment 39. 29-31.

EEA 1995. Europe's environment: the Dobris assessment. Chapter 7. Soil. Copenhagen, European Environment Agency.

EEA 2003. Europe's environment - the third assessment. Environmental Assessment Report No. 10. Copenhagen, European Environment Agency.

EEA 2007. Europe's environment - the fourth assessment. Environmental Assessment Report No. 11. Copenhagen, European Environment Agency. 
EEA 2017. Air quality in Europe - 2017 report. Report No. 13/2017. Copenhagen, European Environment Agency.

Eswaran, H., LaL, R. and Reich, P.F. 1999. Land degradation: an overview. In Responses to Land Degradation. Proceedings of $2^{\text {nd }}$ International Conference on Land Degradation and Desertification. Eds.: Bridges, E.M., Hannam, I.D., Oldeman, L. R., Pening de Vries, F.W.T., Scherr, S.J. and Sompatpanit, S., Khon Kaen, Thailand - New Delhi, India, Oxford Press.

Eurostat 2018. Agri-environmental indicator - soil erosion. Statistics explained. Available at https:// ec.europa.eu/eurostat/statistics-explained/index. php?title=Agri-environmental_indicator_-_soil_ erosion\&oldid $=415938$

FAO 2011. Assessing forest degradation: Towards the development of globally applicable guidelines. Forest Resources Assessment Working Paper 177. Rome, FAO.

FAO 2018. The State of the World's Forests 2018 - Forest pathways to sustainable development. Rome, FAO.

Farkas, J.Zs., Hoyk, E. and RakonczaI, J. 2017. Geographical analysis of climate vulnerability at regional scale: the case of the Southern Great Plain in Hungary. Hungarian Geographical Bulletin 66. (2): 129-144.

FARSANG, A. 2011. Talajuédelem (Soil conservation). Veszprém, Pannon Egyetem Környezetmérnöki Intézet.

Farsang, A., Bartus, M., Barta, K. and Szatmári, J. 2017. Szerkezetes talajok deflációérzékenységének és talajtani tulajdonságainak összefüggései: terepi szélcsatorna kísérletek eredményei dél-alföldi csernozjom talajokon (Connections between wind erosion vulnerability and soil properties of aggregated soils: results of protable wind tunnel experiments on chernozems in the southern part of the Great Hungarian Plain. Földrajzi Közlemények 141. (1): 1-13.

Foley, J.A., De Fries, R., Asner, G.P., Barford, C., Bonan, G., Carpenter, S.R., Chapin, F.S., Coe, M.T., Daily, G.C., Gibbs, H.K. and Helkowski, J.H. 2005. Global consequences of land use. Science 309. 570-574.

GisladottiR, G. and Stоскіng, M. 2005. Land degradation control and its global environmental benefits. Land Degradation and Development 16. (2): 99-112.

Gulácsi, A. and Kovács, F. 2018. Drought monitoring of forest vegetation using MODIS-based normalized difference drought index in Hungary. Hungarian Geographical Bulletin 67. (1): 29-42.

Herrmann, S.M. and Hutchinson, C.F. 2005. The changing context of the desertification debate. Journal of Arid Environments 63. (3): 538-555.

Hosonuma, N., Herold, M., De Sy, V., De Fries, R.S., Brockhaus, M., Verchot, L., Angelsen, A. and
Romijn, E. 2012. An assessment of deforestation and forest degradation drivers in developing countries. Environmental Research Letters 7. 1-12.

Hudson, P.F. and Alcántara-Ayala, I. 2006. Ancient and modern perspectives on land degradation. Catena 65. 102-106.

IFAD 2016. The Drylands Advantage Protecting the Environment, Empowering People. Rome, International Fund for Agricultural Development. Available at https://reliefweb.int/sites/reliefweb.int/files/resources/DrylandsAdv_web.pdf

Imeson, A. 2012. Desertification, Land Degradation and Sustainability. London, Wiley-Blackwell.

IPBES 2018. The Assessment Report on Land Degradation and Restoration. Summary for Policy Makers. Bonn, Germany, Intergovernmental Science-Policy Platform on Biodiversity and Ecosystem Services (IPBES). Available at http://www.ipbes.dk/ wp-content/uploads/2018/09/LandDegradation_ SPM_2018.pdf

IPBES 2019. Global Assessment Report on Biodiversity and Ecosystem Services. Bonn, Germany, Intergovernmental Science-Policy Platform on Biodiversity and Ecosystem Services (IPBES). Available at https://www.ipbes.net/global-assessment-report-biodiversity-ecosystem-services

IPCC 2018. Global Warming of 1.5. Summary for Policy Makers. Geneva, Switzerland, Intergovernmental Panel of Climate Change (IPCC). Available at https://www.ipcc.ch/site/assets/uploads/ sites/2/2018/07/SR15_SPM_version_stand_alone_ LR.pdf

IUCN 2017. Deforestation and Forest Degradation. Gland, Switzerland, International Union for Conservation of Nature Issues Brief.

Johnson, D.L. and Lewis, L.A. 1995. Land Degradation: Creation and Destruction. Oxford, Blackwell.

Józsa, E., Lóczy, D., Soldati, M., Drăguț, L. and Szabó, J. 2019. Distribution of landslides reconstructed from inventory data and estimation of landslide susceptibility in Hungary. Hungarian Geographical Bulletin 68. (3): 255-267.

Kertész, Á. 2009. The global problem of land degradation and desertification. Hungarian Geographical Bulletin 58. (1): 19-31.

Kertész, Á. and ỐrSI, A. 2013. Application of indices for the indication of sensitivity to land degradation and desertification. In Változó föld, változó társadalom, változó ismeretszerzés 2013. A megújuló erőforrások szerepe a regionális fejlesztésben. Eds.: PAJTóKNÉ TARI, I. and Tóth, A. International Scientific Conference, Eger, 10-12. October, 1013. Eger, Agria Geográfia Közhasznú Alapítvány, 55-59.

Kertész, Á., JAKAB, G. and Tóth, A. 2012. Gully erosion risk in Hungary. In Risk analysis VIII: $8^{\text {th }}$ International Conference on Risk Analysis and Hazard Mitigation 2012. Ed.: Brebbia, C.A., Southampton, U.K., WIT Press, 67-76. 
Kertész, Á., Nagy, L.A. and Balázs, B. 2019. Effect of land use change on ecosystem services in Lake Balaton catchment. Land Use Policy 80. 430-438.

Kertész, Á., ÔRsi, A. and Tóth, A. 2015. Identification of sensitivity to land degradation and desertification with respect to landscape services. In International Congress on Landscape Ecology. Understanding Mediterranean Landscapes: Human vs Nature. Eds.: Alphan, H., Atik, M., Baylan, E. and Karadeniz, N., Antalya, Turkey, Landscape Research Society, 155-160.

Kosmas, C., Kirkby, M. and Geeson, N. 1999. The MEDALUS project: Mediterranean desertification and land use. Brussels, European Commission. Available at http://www.kcl.ac.uk/projects/desertlinks/ downloads/publicdownloads/ESA\%20Manual.pdf

Ǩ̌EčEK, J. and HořicKá, Z. 2006. Forests, air pollution and water quality: influencing health in the headwaters of Central Europe's „Black Triangle”. Unasylva 57. 46-49.

Ǩ̌EčEK, J., PALÁn, L. and Stuchlík, E. 2017a. Impacts of land use policy on the recovery of mountain catchments from acidification. Land Use Policy 78. Available at https://doi.org/10.1016/j.landusepol.2017.10.018

Ǩ̌eček, J., Haigh, M., Hofer, T., Kubin, E. and Promper, C. 2017b. Ecosystem Services of Headwater Catchments. Cham, Switzerland, Springer.

Lawler, J.J., Lewis, D.J., Nelson, E., Plantinga, A.J., Polasky, S., Withey, J.C., Helmers, D.P., Martinuzzi, S., Pennington, D. and Radeloff, V.C. 2014. Projected land-use change impacts on ecosystem services in the United States. Proceedings of the National Academy of Sciences 111. (20): 7492-7497. Doi:10.1073/pnas.1405557111

Le Houérou, H.N. 1996. Climate change, drought and desertification. Journal of Arid Environments 34. 133-185.

LundberG, A. 2018. Recent methods, sources and approaches in the study of temporal landscape change at different scales - a review. Hungarian Geographical Bulletin 67. (4): 309-318.

Madarász, B. 2019. Salinization, secondary salinization. In Landscape degradation in Hungary. Ed.: Kertész, Á., Budapest, Geographical Institute, MTA RCAES, (in press).

Millennium Ecosystem Assessment 2006. Ecosystems and Human Well-being. Washington D.C. Island Press. Available at https://www.millenniumassessment.org/en

Négyesi, G., Lóki, J., Bertalan-Balázs, B. and Pásztor, L. 2019. Wind erosion researches in Hungary - past, present and future possibilities. Hungarian Geographical Bulletin 68. (3): 223-240.

Oldeman, L.R., Hakkeling, R.T.A. and Sombroek, W.G. 1991. World Map of the Status of Human-induced Soil Degradation: An Eexplanatory Note. Wageningen
NL - Nairobi Kenya, International Soil Reference and Information Centre and United Nations Environment Programme (UNEP).

PÁlfai, I., Boga, T.L. and Sebesvári, J. 1999. Adatok a magyarországi aszályokról (1931-1998) (Data about droughts in Hungary, [1931-1998]). Éghajlati és Agrometeorológiai Tanulmányok 7. 67-91.

Pásztor, L., Waltner, I., Centeri, Cs., Takács, K. and Laborczi, A. 2015. Magyarország erózió-veszélyeztetettségi térképe (Soil erosion risk map of Hungary). RISSAC 1991. Available at http://www.mta-taki.hu/ hu/osztalyok/gis-labor/agrotopo

Pimentel, D., Allen, J. and Beers, A. 1993. Soil erosion and agricultural productivity. In World Soil Erosion and Conservation. Ed.: Pimentel, D., Cambridge, Cambridge University Press, 277-292.

Reynolds, J.F., StAFFord-Smith, D.M. and Lambin, E. 2003. Do humans cause deserts? An old problem through the lens of a new framework: the Dahlem Desertification Paradigm. In Proceedings of the VII th International Rangelands Congress, 26 July - 1 August 2003. Eds.: Allsopp, N., Palmer, A.R., Milton, S.J., Kirkman, K.P., Kerley, G.I.H., Hurt, C.R. and Brown, C.J., Durban, South Africa, 2042-2048.

Stefanovits, P. and Várallyay, Gy. 1992. State and management of soil erosion in Hungary In Proceedings of the Soil Erosion and Remediation Workshop, US - Central and Eastern European AgroEnvironmental Program, Budapest, 27 April - 1 May 1992. Eds.: Stefanovits, P. and Várallyay, Gr., Budapest, MÉM, 79-95.

Tengberg, A. and Stocking, M. 1997. Erosion-induced loss in soil productivity and its impacts on agricultural production and food security. Paper presented to the FAO/Agritex Expert Consultation on Integrated Soil Management for Sustainable Agriculture and Food Security in Southern and Eastern Africa. Harare, Zimbabwe, 8-12 December 1996.

Tóth, G., Adhikari, K., Várallyay, Gy., Tóth, T., Bódis, K. and Stolbovoy, V. 2008. Updated map of salt affected soils in the European Union. In Threats to Soil Quality in Europe. Eds.: Tóтн, G., Montanarella, L. and Rusco, E., JRC Scientific and Research series. Luxembourg, Office of Official Publications of the European Communities, 61-74.

Turner, B.L., Lambin, E.F. and Reenberg, A. 2008. The emergence of land changes science for global environmental change and sustainability. Proceedings of the National Academy of Sciences of the USA 105. (52): 20666-20671.

UNCCD 2017. Global Land Outlook. Bonn, Germany, UN Convention to Combat Desertification. Available at https://www.unccd.int/sites/default/ files/documents/2017-10/GLO\%20KEY_ESUM-\%20 final-web.pdf

UNCOD 1977. Proceedings of the Desertification Conference. Nairobi-New York, UNEP and Pergamon Press. 
UNEP 1992. World Atlas of Desertification. 69 plates. Nairobi-London, UNEP and Edward Arnold.

UNFF 2017. Six global forest goals agreed at UNFF special session. United Nations Forum on Forests. Available at http://www.un.org/esa/forests/news/2017/01/ six-global-forest-goals/index.html

VÁRALLYAY, GY. 1989. Soil degradation processes and their control in Hungary. Land Degradation and Rehabilitation 1. 171-188.

VÁrallyay, Gy. and Leszták, M. 1990. Susceptibility of soils to physical degradation in Hungary. Soil Technology 3. 289-298.
Vitousek, P.M., Mooney, H.A., Lubchenco, J. and Melillo, J.M. 1997. Human domination of Earth's ecosystems. Science 277. 494-500.

WiLLIS, K.G. 2002. Benefits and costs of forests to water supply and water quality. Social and Environmental Benefits of Forestry. Report to Forestry Commission, Phase 2. New Castle, Centre for Research in Environmental Appraisal and Management, University of Newcastle.

World Population Clock 2019. Available at https://www. worldometers.info/world-population/ 
